\title{
„WROGOŚĆ” W DYSKURSIE POLITYKI FELIPE CALDERONA
}

\author{
Aleksandra Jargiełło \\ Uniwersytet Marii Curie-Skłodowskiej w Lublinie \\ Wydział Politologii i Dziennikarstwa \\ ORCID: https://orcid.org/0000-0002-3776-4050 \\ e-mail: aleksandra.jargiello@poczta.umcs.lublin.pl
}

\begin{abstract}
Streszczenie: Wrogość jest typem postawy zorientowanej wobec konkretnych podmiotów, które można w różny sposób postrzegać i definiować. Artykuł stanowi próbę analizy dyskursu polityki prezydenta Meksyku Felipe Calderona w kontekście tzw. „wojny z kartelami narkotykowymi”. W artykule przede wszystkim zwrócono uwagę na czynniki, które były przesłankami wrogości w dyskursie prezydenta, oraz sposób, w jaki owa wrogość była kreowana. Dla potrzeb podjętego problemu przyjęto tezę, że podmiotem wrogości dyskursu Felipe Calderona były grupy przestępczości zorganizowanej. Założenie uzupełniono dwoma pytaniami badawczymi. Po pierwsze, kartele narkotykowe były wrogiem rzeczywistym (obiektywnym), czy nierzeczywistym (subiektywnym)? Po drugie, czy prezydent traktował kartele narkotykowe jako wroga wewnętrznego, czy zewnętrznego? Głównymi metodami badawczymi, które wykorzystano w artykule, jest metoda czynnikowa oraz analiza dyskursu, za pomocą której zbadano wypowiedzi prezydenta.
\end{abstract}

Słowa kluczowe: wrogość, wróg, dyskurs polityki, Felipe Calderón, przestępczość zorganizowana, kartele narkotykowe

\section{WPROWADZENIE}

We współczesnej historii Meksyku rok 2006 zapisał się jako ważna data za sprawą prezydenta Felipe Calderona, który wypowiedział tzw. wojnę kartelom narkotykowym. W ciągu prawie 13 lat trwania konfliktu, który nie zakończył się wraz ze zmianą administracji rządowej, życie straciło ponad 200000 osób, a 35000 uważa się za zaginione [Correa-Cabrera, Weiss 2019]. Wojna narkotykowa w Meksyku to także konflikt między samymi grupami przestępczymi o zyski finansowe i dostęp do szlaków przemytniczych. Popularne w mediach oraz opracowaniach naukowych określenia: „,wojna Calderona”, „wojna antynarkotykowa”, „wojna z narkotykami”, „wojna z przestępczością zorganizowaną”, 
sugerują, iż podstawową oś konfliktu stanowi walka pomiędzy rządem meksykańskim a kartelami narkotykowymi. Owa wojna znalazła swoje odzwierciedlenie nie tylko w polityce bezpieczeństwa prezydenta Calderona, ale także w stosowanym przez niego dyskursie.

Dyskurs jest formą komunikowania autora/nadawcy danych treści z adresatem/odbiorcą lub komunikowania odbiorcy pewnych idei, światopoglądów, komentarzy, sądów itp. [Kujawa 2009: 48]. Ze sferą polityki związanych jest kilka rodzajów dyskursu. Marek Czyżewski, Sergiusz Kowalski i Andrzej Piotrowski w książce Rytualny chaos. Studium dyskursu publicznego [Czyżewski, Kowalski, Piotrowski 2010: 18-29] rozróżnili i zdefiniowali: dyskurs publiczny, dyskurs polityczny oraz dyskurs polityki. Według nich dyskurs publiczny dotyczy wszelkiej komunikacji dostępnej publicznie - w sposób bezpośredni oraz pośredni przez media drukowane i audiowizualne. Natomiast dyskurs polityczny obejmuje dyskurs elit symbolicznych danego społeczeństwa na tematy polityczne. Pod pojęciem „elita symboliczna” należy rozumieć ludzi sprawujących kontrolę nad wiedzą dostępną publicznie, którzy określają hierarchię spraw i wartości, innymi słowy sprawują władzę nad środkami komunikowania masowego. Najwęższą spośród wyżej wymienionych kategorii jest kategoria dyskursu polityki. Obejmuje ona „,wypowiedzi polityków w ramach ról przypisanych im w obrębie instytucji politycznych" [Czyżewski, Kowalski, Piotrowski 2010: 22-23] i stanowi jedynie część dyskursu politycznego oraz publicznego. Strukturę dyskursu tworzą pojedyncze teksty w formie mówionej i pisanej z obszaru komunikacji politycznej, które dzięki wzajemnemu oddziaływaniu tworzą pewnego rodzaju sploty, relacje oraz zależności. Tym, co je łączy, jest wspólny temat oraz określony wycinek czasoprzestrzeni, nadający dyskursowi pewne ramy. Szczególne znaczenie ma także aspekt związany z intencjami autora. W dyskursie polityki głównym odbiorcą tekstów jest społeczeństwo, stąd wykorzystane przez nadawcę środki językowe są najczęściej podporządkowane funkcji perswazyjnej. Służą one nakłonieniu masowego odbiorcy do takich działań, które są zgodne z intencją nadawcy, np. do przyjęcia lub odrzucenia określonych idei, poglądów bądź do zaakceptowania narzuconej hierarchii wartości [Kujawa 2009: 47-50].

Niniejszy artykuł stanowi próbę przeprowadzenia analizy dyskursu polityki prezydenta Felipe Calderona w kontekście polityki bezpieczeństwa jego administracji ${ }^{1}$ wobec zjawiska przestępczości zorganizowanej, znanej pod symboliczną nazwą , wojna z kartelami narkotykowymi”. Według Carla Schmitta ,wojna wynika z wrogości”’2. Wrogość natomiast jest pojęciem trudnym do zdefiniowania. Na potrzeby artykułu będzie ona rozumiana jako stan, relacja między stronami, która charakteryzuje się: niechęcią, antypatią, odrazą, agresywnością czy napastliwością. To także typ postawy negatywnej o cechach emocjonalnych i agresywnych

1 Meksyk jest państwem o systemie prezydenckim, kadencja prezydenta trwa 6 lat bez możliwości reelekcji.

2 Cyt. za: [Ziółkowski 2013: 44]. 
wobec konkretnego podmiotu, którego wybór może być przypadkowy lub instrumentalny [Ziółkowski 2013: 30-31]. Celem pracy jest wskazanie czynników, które były przesłankami wrogości w dyskursie Felipe Calderona, oraz ukazanie, w jaki sposób owa wrogość była przez prezydenta kreowana. W pracy postawiono tezę, iż podmiotem wrogości Felipe Calderona były grupy przestępczości zorganizowanej. Założenie uzupełniono dwoma pytaniami badawczymi. Po pierwsze, czy wróg w postaci karteli narkotykowych ${ }^{3}$ był wrogiem rzeczywistym (obiektywnym), czy nierzeczywistym (subiektywnym)? Po drugie, czy prezydent traktowal kartele narkotykowe jako wroga wewnętrznego czy zewnętrznego? Głównymi metodami badawczymi, które wykorzystano w artykule, jest metoda czynnikowa oraz analiza dyskursu. Rozważania oparto na różnorodnej bazie źródłowej, przede wszystkim na: przemówieniach prezydenta, programach bezpieczeństwa, raportach oraz literaturze przedmiotu.

\section{DETERMINANTY WROGOŚCI W DYSKURSIE POLITYKI FELIPE CALDERONA}

Felipe de Jesus Caderon Hinojosa urodził się 18 sierpnia 1962 roku w Morelia w stanie Michoacán, w rodzinie o tradycjach politycznych, jednej z założycieli chrześcijańsko-konserwatywnego ugrupowania Partii Akcji Narodowej (PAN). Ukończył prawo, ekonomię i studia MBA na Harwardzie. W wieku 26 lat zajął się polityką. Był deputowanym, przewodniczącym PAN, a w 2004 roku został ministrem ds. energii [Grillo 2012: 158]. Urząd głowy państwa objął w 2006 roku po wygraniu burzliwych wyborów prezydenckich, w których uzyskał 35,89\% głosów, jedynie o 0,6\% więcej od swojego politycznego przeciwnika Andresa Manuela Lopeza Obradora z Partii Rewolucji Demokratycznej (PRD) [Debra, Kohler 2008]. Dla dużej części społeczeństwa taki wynik wyborów świadczył o manipulacji i fałszerstwie [Sánchez Díaz de Rivera 2011].

Znaczna część ekspertów jest zdania, iż Calderón po wygraniu wyborów z niewielką przewagą głosów nad przeciwnikiem zajął się narkowojną, przesuwając tym samym priorytety swojej polityki na kwestię bezpieczeństwa ${ }^{4}$, aby uzyskać efekt medialny oraz zdobyć popularność i legitymizację, której mu brakowało [Wiśniewski 2010]. Według Jacka Ziółkowskiego, „wróg legitymizuje

3 W artykule określenia: „grupy przestępczości zorganizowanej”, „grupy przestępcze”, „kartele narkotykowe”, będą używane zamiennie, ze względu na fakt iż kartele narkotykowe są pewnym specyficznym rodzajem przestępczości zorganizowanej, ponadto dywersyfikują źródła swoich przychodów, stąd uzasadnione jest je nazywać grupami przestępczości zorganizowanej.

4 Podczas swojej kampanii prezydent mówił, że plan działania jego rządu będzie się opierać na koncepcji zrównoważonego rozwoju, a do głównych obszarów polityki zaliczał: praworządność, bezpieczeństwo publiczne, konkurencyjność gospodarki oraz tworzenie nowych miejsc pracy, równość szans, efektywną demokrację i odpowiedzialną politykę zagraniczną. Zob.: [Presidente Felipe Calderón... 2006]. 
system na poziomie konkretnych osób, polityków, rządzących. [...] wróg jest elementem wykorzystywanym do rywalizacji o przywództwo polityczne, rozumianej personalnie. Liderzy polityczni taktują walkę z wrogiem jako element akredytacyjny, który wykazywać ma ich sprawność, wiarę w sprawę, zaangażowanie" [Ziółkowski 2013: 181]. Jest to wymiar legitymizacji personalnej w obecności wroga, którym w przypadku Meksyku były kartele narkotykowe.

W kontekście przywództwa politycznego José Luis Méndez podkreślił [Méndez 2015: 116-170], że Calderón stanął w obliczu niekorzystnych okoliczności, ponieważ doszedł do władzy jako ,afiliowany” prezydent - nie miał zbyt wiele miejsca na prezentowanie nowatorskich propozycji i musiał stawiać czoła ryzyku bycia postrzeganym jako „cień” poprzedniego prezydenta 5 . Fox, który miał być „rekonstruktorem nowego porządku”, nie zrealizował wielu ze swoich deklaracji ${ }^{6}$, co teoretycznie dawało Calderonowi możliwość zostania „ortodoksyjnym innowatorem" oraz aktywnym politykiem i zarazem zdystansowania się od poprzednika. Zdaniem Méndeza, Calderón miał wiele możliwości, aby nie być zwykłym „konsolidatorem” demokracji w okresie transformacji, ale stać się jej prawdziwym „konstruktorem". Prezydent z pewnością był świadomy roli, jaką przyszło mu pełnić7.

Należy pamiętać, iż obejmując urząd, zastał państwo w stanie konfliktu, wojny pomiędzy kartelami narkotykowymi, której początek sięga lat 90. XX wieku. Od tamtej pory kartele zaczęły dywersyfikować źródła swoich przychodów oraz inwestować w uzbrojenie i budować prywatne armie ${ }^{8}$. Chociaż z perspektywy czasu przemoc związana z narkotykami w tamtym okresie wyglądała bardzo łagodnie, to liczba zabójstw w trakcie prezydentury Foxa podwoiła się w stosunku do poprzedniej administracji [Small Arms Survey 2012: 42-56]. W 2004 roku odnotowano 1304 morderstwa związane z kartelami; w 2005 roku więcej, bo 1776, zaś w 2006 roku aż $2100^{9}$. Należy podkreślić, że służby państwowe odpowiedzialne za zapewnienie bezpieczeństwa publicznego były zbyt słabe, żeby poradzić sobie z efektyw-

5 Chodzi o prezydenta Vincente'a Foxa z partii PAN, który objął urząd w 2000 r., co dało początek transformacji demokratycznej Meksyku i zakończyło 71 lat rządów autorytarnych Partii Rewolucyjno-Instytucjonalnej. Zob.: [Derwich 2009: 45].

6 Foxowi nie udało się przeprowadzić w pełni m.in. reformy: fiskalnej, emerytalnej, energetycznej, wyborczej, edukacji, bezpieczeństwa i telekomunikacyjni. Zob.: [Méndez 2015].

7 Świadczy o tym chociażby fakt, iż w 2011 r. zapytany przez dziennikarza z Radio Fórmula, dlaczego dopiero w dość niekorzystnej sytuacji politycznej przestawił przed Kongresem pakiet ważnych reform, Calderón odpowiedział: „Nie chcę być zapamiętany jako kolejny prezydent”. Cyt. za: [Méndez 2015: 126].

8 Szczególnie brutalną była grupa Los Zetas stworzona przez byłych komandosów meksykańskiej jednostki specjalnej, którzy początkowo pracowali jako wynajęci mordercy i ochroniarze dla Kartelu Zatokowego. Dzięki dyscyplinie wojskowej, dostępowi do broni i informacji grupa szybko uzyskała przewagę nad kartelem i stworzyła autonomiczną strukturę. Zob.: [InSight Crime 2010].

9 Przemoc była szczególnie widoczna w Michoacán, rodzinnym stanie Calderona, gdzie w 2006 r. zarejestrowano ponad 500 morderstw, w tym incydent, który zyskał międzynarodową uwagę, kiedy to bandyci w jednej z dyskotek rzucili na parkiet pięć odciętych ludzkich głów. Zob.: [Peña Nieto’s Challenge... 2013]. 
nym zwalczaniem przestępczości zorganizowanej. Meksykańska policja zmagała się z korupcją oraz deficytem zaufania wśród obywateli. Dlatego jedyną realną opcją w walce $\mathrm{z}$ kartelami było użycie wojska, które cieszyło się dużym zaufaniem publicznym. Świadczą o tym wyniki badań przeprowadzone przez ośrodek badań rynku i opinii publicznej w Meksyku Consulta Mitofsky. Według nich w 2006 roku swój poziom zaufania do policji mieszkańcy Meksyku w skali 1-10 ocenili na 5,9; zaś do wojska na 7,9 [Programa Nacional... 2009]. Mając na uwadze powyższe czynniki, nie dziwi fakt, iż społeczeństwo meksykańskie, będące w sytuacji poczucia zagrożenia ze strony grup przestępczych, tym samym nie ufając skorumpowanej policji, która często współpracowała z kartelami, domagało się od władzy użycia bardziej radykalnych środków w celu zapewnienia bezpieczeństwa publicznego [Sotomayor 2013: 42-60]. Jednak można zadać pytanie, na ile miały być one radykalne i czy faktycznie obywatele Meksyku uważali kartele narkotykowe za swojego wroga, biorąc pod uwagę fakt, iż w kulturze meksykańskiej istnieje społeczna akceptacja narkobiznesu ${ }^{10}$, a substancje psychoaktywne pełniły bardzo ważną rolę wśród ludności rdzennej już w czasach prekolumbijskich [Drzewiecka 2009: 81].

Analizując czynniki, które wpłynęły na wrogość dyskursu Felipe Calderona wobec grup przestępczości zorganizowanej, a w konsekwencji na prowadzoną przez prezydenta politykę, należy wziąć pod uwagę również środowisko międzynarodowe. Stany Zjednoczone Ameryki, które pierwsze wypowiedziały wojnę narkotykom ${ }^{11}$, od dawna angażowały się w pomoc państwom Ameryki Łacińskiej w zwalczaniu narkobiznesu. Administracja amerykańska zarzucała rządowi meksykańskiemu brak skupienia na tej kwestii. Uważała, że władze tego państwa przymykają oko na narkobiznes i dopuszczają się korupcji [Olson 2017]. Wydarzenia, które miały miejsce na początku XXI wieku, niewątpliwie wpłynęły na politykę bezpieczeństwa regionu. Po atakach z 11 września 2001 r. ówczesny prezydent USA George W. Bush wypowiedział wojnę terroryzmowi, co w rezultacie oznaczało, że Stany Zjednoczone Ameryki zaczęły traktować narkotyki i terroryzm jako zagadnienia nierozerwalnie ze sobą związane [Drzewiecka 2009: 70] i wywierać coraz większy nacisk na władze Meksyku, aby te podjęły odpowiednie środki w celu ograniczenia działalności grup transnarodowej przestępczości zorganizowanej zajmujących się produkcją i handlem narkotykami.

${ }^{10}$ Uprawa roślin, z których później wytwarzane są narkotyki, jest często bardziej opłacalna niż uprawa kukurydzy, zaś ich produkcja i dystrybucja stanowi niekiedy jedyną szansę na wyrwanie się z ubóstwa i poprawę sytuacji materialnej. Stąd spora część młodzieży pracuje na zlecenie lokalnych gangów czy karteli narkotykowych, których liderzy zapewniając opiekę socjalną i bezpieczeństwo na danym terytorium, cieszą się dość dużym poparciem wśród miejscowej ludności. Przywódcy karteli narkotykowych stają się kimś w rodzaju „ojców chrzestnych”, którzy są żywicielami, sponsorami i dobrodziejami, fundującymi budowę boisk, szpitali i kościołów. Zob.: [Skowronek 2014].

${ }^{11}$ Pierwszy raz termin „wojna narkotykowa” został użyty przez prezydenta Stanów Zjednoczonych Richarda Nixona. W 1971 r. podczas swojego przemówienia powiedział, że „narkotyki” są , wrogiem publicznym numer jeden” i zapoczątkował wojnę z substancjami odurzającymi. Zob. rozprawa doktorska: [Drzewiecka 2015: 140-141]. 


\section{KREOWANIE WROGOŚCI PRZEZ FELIPE CALDERONA}

Wrogość jest typem postawy zorientowanej wobec konkretnych podmiotów, które można w różny sposób postrzegać i definiować. Prezydent Calderón w swoich wypowiedziach odwoływał się do alegorii ludzkiego ciała: „Wiem, że Meksyk stoi w obliczu dużego problemu bezpieczeństwa. Jest to nowotwór, który wylęgał się przez lata i nie poświęcono mu należytej uwagi, ale jest to rak, który zamierzamy wyeliminować"12. Przytoczona powyżej wypowiedź pochodzi z Drugiego Raportu Rządowego (Segundo Informe de Gobierno), a jej odbiorcą jest meksykańskie społeczeństwo. Nadawca informacji opisuje rzeczywistość - główny problem państwa, którym jest narkobiznes. Przedstawia go jako zło, „raka społecznego”, poważną chorobę, która dawała symptomy przez dłuższy czas, jednak była bagatelizowana lub źle leczona, co należy rozumieć jako zaniedbanie ze strony poprzednich administracji. Calderón zobowiązał się, że jego rząd podejmie odpowiednie działania - niczym lekarz, który wyleczy chorobę, wytnie chorą tkankę, przy założeniu, że tego typu leczenie może osłabić organizm, co w praktyce oznacza, że zwalczanie narkoprzestępczości będzie się wiązało z poniesieniem kosztów społecznych.

Prezydent często w swoich wypowiedziach posługiwał się wojenną retoryką, mówił: „Przestępczość zorganizowana dąży do kontroli terytorialnej, będzie to wojna bez litości, ponieważ już nie ma możliwości na współistnienie z narco ${ }^{13}$. Nie ma powrotu; oni albo my"14. Wypowiedź sugeruje, iż jej nadawca nie przewiduje porozumienia pomiędzy stronami, a głównym celem działań (wojennych) ma być zniszczenie wroga, aby nie mógł on przeprowadzić kontrataku. Widoczny jest tu dychotomiczny podział na „my-oni”, co stanowi fundamentalną zasadę kreowania wrogości w stosunkach społecznych [Ziółkowski 2013: 158]. Owe „my” to grupa posiadająca własną tożsamość, według Calderona tworzy ją społeczeństwo meksykańskie, ludzie niezwiązani z narkobiznesem - jak on sam. Opozycją do „my” są „oni”, czyli „obcy”, „inni”, osoby zajmujące się działalnością przestępczą, traktowane przez prezydenta nie jako część społeczeństwa, ale jako ktoś z zewnątrz. Zygmunt Bauman podkreślił, iż ,»inni« są tym przeciwstawnym obrazem, którego my potrzebujemy dla własnej tożsamości, dla spójności grupy, jej solidarności i emocjonalnej stabilności” ${ }^{15}$. Potrzeby te przyświecały także

12 „Sé que México enfrenta un gran problema de seguridad. Éste es un cáncer quese ha venidoincubandoduranteaños y al que no se le dio la debidaatención, pero es uncáncerquevamos a erradicar". Przesłanie prezydenta do narodu na temat bezpieczeństwa w ramach Drugiego Raportu Rządowego, opublikowane 25 sierpnia 2008 r. Zob.: [Mensaje a la ... 2008].

${ }^{13}$ Narco w języku potocznym oznacza przemytnika narkotyków, a w szerszym ujęciu narkobiznes.

14 „El crimenorganizadobusca el controlterritorial, seráunaguerra sin cuartelporqueya no hayposibilidad de convivir con el narco. No hayregreso; sonellos o nosotros". Wypowiedź Calderona z 27 lutego 2009 r. Cyt. za: [Manaut 2009: 173].

15 Cyt. za: [Zieliński 2013: 159]. 
Calderonowi, który - jak już wcześniej zostało wspomniane - chciał uzyskać legitymizację i poparcie społeczne dla swojej polityki.

Symbolicznym wydarzeniem podczas 6-letniej prezydentury Calderona była jego wizyta w bazie wojskowej w Michoacán, którą złożył 3 stycznia 2007 r. w celu przeglądu postępów realizowanej kampanii. Media obiegły zdjęcia prezydenta ubranego w oliwkową kurtkę i wojskową czapkę, pozdrawiającego swoich żołnierzy, co stanowiło przełamanie pewnej tradycji unikania noszenia wojskowych strojów przez współczesnych prezydentów [Grillo 2012: 161]. Postawa ta stanowi pewien kod ubraniowy, który pomaga dostosować się do danej sytuacji i wejść w określoną rolę społeczną, w przypadku Calderona była to rola generała, który wydaje rozkazy i zagrzewa swoich żołnierzy do walki.

To właśnie element walki i kategoria „,wróg-sojusznik” zdominowały dyskurs polityczny Calderona: „Dzisiaj wrogowie Meksyku starają się wpłynąc na rozwój naszego narodu, Meksyk wzywa nas wszystkich, jak zawsze, do jego obrony. Dzisiaj musimy chronić nasze rodziny przed tymi, którzy zagrażają ich pokojowi i spokojowi, przed wrogami Meksyku, którzy poprzez akty kryminalne starają się wyrządzić krzywdę życiu i dziedzictwu, które my Meksykanie zbudowaliśmy z takim wysiłkiem. Przeciwko tym, którzy zagrażają bezpieczeństwu i pokoju naszego narodu, Meksyk w sposób jasny i stanowczy domaga się jedności swoich dzieci"16.

Kategoria ta przywodzi na myśl filozofię Carla Schmitta, według którego naturę polityczności czy polityki stanowi konflikt między „wrogiem” a „sojusznikiem". Wrogość jest cechą przynależną zbiorowości ludzi, która powstaje w sytuacji konfliktu charakteryzującego się możliwością negacji egzystencji innego zbiorowego bytu. Wrogość tym samym jest kluczowym warunkiem samookreślenia grupy, integracji jej członków i odczuwania przez nich wspólnej tożsamości. Uświadamia ona „sojusznikom” (,przyjaciołom”), że stanowią jedność, której zagraża obcy, czyli „wróg”. Schmitt stwierdził, iż właściwą postawą wobec wroga jest walka, rozumiana jako wojna. Zaś ostateczną decyzję o wojnie i zastosowaniu nieograniczonych metod podejmuje suweren, który reprezentuje ogół, a w swoim postępowaniu kieruje się interesem państwa, dlatego też decyzja ta ma samoistną wartość [Sepczyńska 2010: 177-221].

Przytoczona powyżej wypowiedź Calderona wkomponowuje się w koncepcję Schmitta: suwerenem jest w tym przypadku ${ }^{17}$ prezydent, reprezentujący społeczeństwo meksykańskie, sojusznik to obywatele, zaś wrogiem są grupy

16 „Hoy los enemigos de México buscan afectar el desarrollo de nuestra Nación, México nos llama a todos, comosiempre, a defenderlo. Hoydebemosproteger a nuestrasfamilias de quienesatentan contra su paz y sutranquilidad, de los enemigos de Méxicoquebuscandañar con actoscriminales la vida o el patrimonioque con tanto esfuerzohemosconstruido los mexicanos. Frente a quienesamenazas la seguridad y la paz de los nuestros, Méxicoreclama la unidad de sus hijos de maneraclara y contundente". Przemówienie prezydenta podczas ceremonii zamknięcia i otwarcia kursów obozów wojskowych 14 września 2007. Cyt. za: [Castillo Lopez 2013: 40-41].

${ }^{17}$ Należy zaznaczyć, że w państwie o ustroju demokratycznym suwerenem jest naród sprawujący władzę przez swoich przedstawicieli lub bezpośrednio. 
przestępczości zorganizowanej. Ponadto zawiera ona duży ładunek emocjonalny, prezydent odwołuje się do najwyższej wartości, czyli do narodu, który stoi przed zagrożeniem ze strony karteli narkotykowych. Wypowiedź ma na celu nakłonienie odbiorcy, którym w tym przypadku są młodzi adepci sztuki wojennej, do obrony ojczyzny. Prezydent, nawiązując do historii Meksyku (co prawda nie przywołuje konkretnych wydarzeń, jednak wspomina o wysiłku budowania dziedzictwa), wywiera na odbiorcę nacisk, przypominając o obowiązku, jakim jest obrona narodu.

Warto podkreślić, iż prezydent postrzegał kartele narkotykowe nie tyle jako wroga wewnętrznego, który stanowi zagrożenie dla bezpieczeństwa publicznego i którego zwalczaniem powinna zająć się policja, korpus cywilny, szkolony w zakresie zwalczania zagrożeń właśnie dla bezpieczeństwa publicznego, wykorzystujący możliwie najmniejszą siłę we współpracy z obywatelami. Dla Calderona są one także wrogiem zewnętrznym, zagrażającym bezpieczeństwu narodowemu państwa, stąd też do ich zwalczania powinien zostać włączony personel wojskowy przeszkolony w sytuacjach bojowych, w których siła używana jest do walki z uzbrojonym wrogiem. W zasadzie prezydent traktował bezpieczeństwo publiczne jako synonim bezpieczeństwa narodowego ${ }^{18}$, stąd decyzja o militaryzacji działań przeciwko grupom przestępczości zorganizowanej ${ }^{19}$. Znalazła ona swoje odzwierciedlenie w Programie Bezpieczeństwa Narodowego [Programa para... 2009], który zakładał, iż bezpieczeństwo narodowe obejmuje obronę meksykańskiego narodu przed zagrożeniami i ryzykiem stojącym przed państwem, ze strony grupy zbrojnych oraz grup przestępczości zorganizowanej. Strategia bezpieczeństwa polegała m.in. na zmuszeniu karteli narkotykowych do ataku frontalnego i rozbiciu ich za pomocą sił wojskowych, tym samym odzyskiwaniu stref publicznych zajętych przez kartele. Kolejnym, długoterminowym etapem strategii było oczyszczenie instytucji państwowych ze skorumpowanych funkcjonariuszy. Administracja skupiła się również na aresztowaniu przywódców karteli narkotykowych przy pomocy żołnierzy marynarki wojennej. Zaś wszystkie te działania uzyskały aprobatę i wparcie ze strony rządu Stanów Zjednoczonych Ameryki $^{20}$.

${ }^{18}$ Marcos Pablo Moloeznik stwierdził, że w Meksyku bezpieczeństwo wewnętrzne stanowi XIX-wieczny relikt, który przetrwał w tym państwie jako misja sił zbrojnych. Wymiar bezpieczeństwa nie jest zdefiniowany, brakuje regulacji prawnych, stąd też często jest ono wykorzystywane przez prezydentów jako synonim bezpieczeństwa narodowego. Zob.: [Moloeznik 2014].

${ }_{19}$ Militaryzacja zwalczania przestępczości narkotykowej w Meksyku nie jest niczym nowym. Rozpoczęła się pod koniec lat 80. XX wieku, w okresie rządów Salinasa de Gortari, przez określenie w Narodowym Planie Rozwoju, iż przemyt narkotyków jest poważnym zagrożeniem dla bezpieczeństwa narodowego państwa. Kolejne administracje wprowadzały reformy, przyczyniające się do dalszej militaryzacji. W okresie prezydentury Calderona działania te przybrały na sile. Zob. rozprawa doktorska: [Drzewiecka 2015: 145-155].

${ }^{20}$ W roku 2007 współpraca obu państw w walce z przestępczością weszła na wyższy wymiar za sprawą Inicjatywy Merida polegającej m.in. na wysyłaniu samolotów i pojazdów, transferze technologii oraz na szkoleniach. Pogłębiła ona tylko proces militaryzacji. Zob.: [Jargiełło 2018: 55-60]. 


\section{KONKLUZJE}

Prezydent Felipe Calderón zapisał się w historii Meksyku jako lider polityczny, który wypowiedział wojnę kartelom narkotykowym. Na wrogość jego dyskursu wpłynęło wiele czynników, które były ze sobą wzajemnie powiązane. Miały one związek zarówno z sytuacją społeczno-ekonomiczną państwa, którą nowo wybrany prezydent zastał, jak i z funkcjonowaniem systemu politycznego oraz ze środowiskiem międzynarodowym. W okresie dojścia do władzy Felipe Calderona meksykańskie kartele narkotykowe generowały w państwie przemoc, zaś policja odpowiedzialna za zapewnienie bezpieczeństwa publicznego nie spełniała należycie swojej funkcji, więc cieszące się dużym zaufaniem społecznym wojsko pozostawało jedyną opcją do walki z grupami przestępczości zorganizowanej. Ponadto wpływ na dyskurs prezydenta miała polityka antynarkotykowa Stanów Zjednoczonych Ameryki oparta na militaryzacji i kryminalizacji. Czynniki te świadczą o tym, że wrogość Calderona wynikała z przesłanek zobiektywizowanych. W proces kreacji wrogości były także zaangażowane czynniki psychologiczne związane z osobą prezydenta ${ }^{21}$. W opinii Calderona najlepszą metodą na uzyskanie legitymizacji społecznej było wykreowanie wroga, w walce z którym nowo wybrany prezydent mógłby się wykazać jako polityk dbający o bezpieczeństwo państwa i dobro obywateli, co zarazem zaspokoiłoby jego ambicje polityczne, które bez wątpienia posiadał. Poglądy Calderona wynikały również z systemu wartości, które preferował. Wywodził się bowiem z rodziny o poglądach konserwatywno-chrześcijańskich, aktywnej na scenie politycznej, stąd bliska mu była ,polityka silnej ręki” (mano dura).

Na podstawie niniejszych rozważań trudno jest jednoznacznie określić, czy wróg w postaci grup przestępczości zorganizowanej był wrogiem subiektywnym (nierzeczywistym) czy obiektywnym (rzeczywistym). Można dojść do wniosku, iż w przypadku Meksyku mamy do czynienia z tzw. ,,paradoksem wroga rzeczywistego a nierzeczywistego" 22 , który polegał na tym, że podmiot (rząd Calderona) postawiony w sytuacji nierzeczywistego zagrożenia (kartele narkotykowe, które nie mają ambicji politycznych, ale stosują przemoc jako środek do zwiększania zysków ekonomicznych) reaguje, tworząc atmosferę zagrożenia (dyskurs i polityka antynarkotykowa) czy wręcz prowokuje swoich „wrogów” do wrogich działań, co tworzy spiralę agresywnych zachowann ${ }^{23}$. Wróg zdefiniowany jako

${ }^{21}$ Kwestią sporną pozostają czynniki związane ze stanem emocjonalnym prezydenta, które mogły wpłynąć na jego dyskurs i prowadzoną przez niego politykę. Otóż Felipe Calderón miał problemy związane z nadużywaniem alkoholu. Jednak trudno jest obiektywnie stwierdzić, czy i w jakim stopniu problemy te wpłynęły na postrzeganie przez prezydenta rzeczywistości oraz proces decyzyjny.

${ }^{22}$ O tzw. „paradoksie wroga rzeczywistego a nierzeczywistego” pisał Jacek Ziółkowski. Zob.: [Ziółkowski 2013: 262].

${ }^{23}$ Polityka silnej ręki w Meksyku wobec narkobiznesu doprowadziła do eskalacji przemocy i wzrostu wskaźnika morderstw. Zob.: [Calderón, Heinle, Rodríguez Ferreira, Shirk 2019]. 
grupy przestępczości zorganizowanej był tak naprawdę częścią meksykańskiego społeczeństwa (rzeczywistości), jednak prezydent postrzegał go jako wroga zewnętrznego, zagrażającego bezpieczeństwu narodowemu państwa.

Reasumując, zastosowanie przez Calderona w swojej retoryce narzędzi perswazyjnych, w postaci licznych metafor i porównań, które odnoszą się do wrogości, oraz uczynienie ze społeczeństwa meksykańskiego zbiorowego zamierzonego odbiorcy wypowiedzi umożliwiło prezydentowi dokonanie sekurytyzacji ${ }^{24}$ przestępczości zorganizowanej, co pozwoliło na militaryzację zwalczania narkobiz$n^{n e s u}{ }^{25}$. Należy mieć na uwadze, iż kwestie poruszone w niniejszym artykule dają jedynie ogólny zarys problemu. Pewne wątki warte są rozszerzenia i dalszego zbadania, jak chociażby kwestia dynamiki wrogości - czy wrogość zmieniała się wraz z upływem czasu (kadencji prezydenckiej), czy przybierała na sile i co było tego przyczyną. Kwestia ta jest ciekawa z uwagi na fakt, iż na przestrzeni lat poglądy Felipe Calderona uległy zmianie - w połowie swojej prezydentury ogłosił [Jargiełło 2018: 57], iż priorytetem jego polityki będzie ograniczenie ubóstwa i tworzenie nowych miejsc pracy.

Title: "Hostility" in the Policy Discourse of Felipe Calderón

Summary: Hostility is a type of attitude, which is directed to specific entities that can be perceived and defined in a different way. This article is an attempt to analyze the discourse of the president of Mexico, Felipe Calderón in the context of the so-called "drug war". The author primarily focused on factors that were the premises of hostility in the discourse and on the way in which this hostility was created by the president. The organised crime groups as a main enemy in Felipe Calderón's discourse is the topic of this research. The assumption was supplied with two research questions. First, were drug cartels a real (objective) or unreal (subjective) enemy? Second, did the president treat drug cartels as an internal or external enemy? The factor analysis and discourse analysis of president's statements are the main research methods.

Keywords: hostility, enemy, policy discourse, Felipe Calderón, organized crime, drug cartels

${ }^{24}$ Sekurytyzacja to proces, w którym podmiot, np. lider polityczny, przez użycie odpowiedniego języka wskazuje jakiś proces, temat lub inny podmiot ,jako egzystencjalne zagrożenie”, przy czym odbiorca aktu sekurytyzacji musi uznać tę kwestię za zagrożenie i wyrazić zgodę na użycie „nadzwyczajnych środków” w celu zapewnienia bezpieczeństwa. Zob.: [McDonald 2012: 69].

${ }_{25}$ Zagadnienie sekurytyzacji przestępczości zorganizowanej w Meksyku i militaryzacji bezpieczeństwa zostało poruszone w artykule Założenia strategii bezpieczeństwa Felipe Calderona i Enrique Peña Nieto w zakresie zwalczania przestępczości zorganizowanej w Meksyku. Zob.: [Jargiełło 2018]. 


\section{BIBLIOGRAFIA}

1. Calderón L. Y., Heinle K., Rodríguez Ferreira O., Shirk D. A (2019), Organized Crime and Violence in Mexico, Analysis Through 2018, https://justiceinmexico.org/wp-content/uploads/2019/04/Organized-Crime-and-Violence-in-Mexico-2019.pdf [dostęp: 20.06.2019].

2. Castillo Lopez C. (2013), El Presidente Calderón en la ceremonia de clausura y apertura de cursos de los plantelesmilitares, [w:] Discursospresidenciales Felipe Calderon Hinojosa I. Estado de derecho y seguridad, Federacion Rafael Preciado Hernández, A.C., Mexico Districto Federal, https://issuu.com/frph/docs/d_presidenciales_fch_flb7de68888db6 [dostęp: 22.06.2019].

3. Correa-Cabrera G., Weiss L. (2019), El Chapo and Mexico's Drug War Spectacle, https:// nacla.org/news/2019/03/04/el-chapo-and-mexico\%E2\%80\%99s-drug-war-spectacle [dostęp: 22.06.2019].

4. Czyżewski M., Kowalski S., Piotrowski A. (red.) (2010), Rytualny chaos. Studium dyskursu publicznego, Warszawa.

5. Derwich K. (2009), Prezydentura Vincente Foxa - sukces czy porażka?, [w:] Meksyk w XXI wieku. Polityka - społeczeństwo - gospodarka, red. K. Derwich, Kraków.

6. Drzewiecka U. (2009), Przemyst narkotykowy jako kluczowy problem polityczno-spoleczny Meksyku, [w:] Meksyk w XXI wieku. Polityka-społeczeństwo-gospodarka, red. K. Derwich, Kraków.

7. Drzewiecka U. (2015), Polityka antynarkotykowa w Meksyku: uwarunkowania społeczno-kulturowe, Kraków [rozprawa doktorska].

8. Grillo I. (2012), El Narco. Narkotykowy zamach stanu w Meksyku, Warszawa.

9. InSight Crime (2010), Zetas, https://www.insightcrime.org/mexico-organized-crime-news/zetas-profile/ [dostęp: 13.06.2019].

10. Jargiełło A. (2018), Założenia strategii bezpieczeństwa Felipe Calderona i Enrique Peñi Nieto w zakresie zwalczania przestępczości zorganizowanej w Meksyku, „Ameryka Łacińska”, 1 (99), http://amerykalacinska.com/ojs/index.php/al/article/view/932/775 [dostęp: 10.06.2019].

11. Kujawa I. (2009), Strategie dyskursu polityki a medialny obraz świata (na materiale wspótczesnej prasy niemieckiej), „Annales”, vol. XVII, sectio FF, Lublin, http://dlibra.umcs.lublin.p1/ Content/21701/czas17868_27_2009_4.pdf [dostęp: 20.06.2019].

12. Manaut R. B. (2009), La crisis de seguridad en Mexico, "La revista Nueva Sociedad", No 220, marzo-abril, https://nuso.org/media/articles/downloads/3601_1.pdf [dostęp: 30.06.2019].

13. McDonald M. (2012), Konstruktywizm, [w:] Studia bezpieczeństwa, red. P.D. Williams, Kraków.

14. Méndez J. L. (2015), El liderazgopolítico en la presidencia de Felipe Calderón (2006-2012), "Foro Internacional", vol. LV, 1 (219), enero-marzo, https://forointernacional.colmex.mx/index. php/fi/article/view/2264 [dostęp: 18.06.2019].

15. Mensajes a la Nación del Presidente Felipe Calderón, en el marco de su Segundo Informe de Gobierno. Del 25 de agosto al 5 de septiembre de 2008 (2008), http://www.biblioteca.tv/ artman2/publish/2008/Mensajes_a_la_Naci_n_del_Presidente_Felipe_Calder_n_en_el_marco_de_su_Segundo_Informe_de_Gobierno_printer.shtml [dostęp: 14.06.2019].

16. Meyer M. (2013), Mexico's New Military Police Force: The Continued Militarization of Public Security in Mexico, https://www.wola.org/analysis/mexicos-new-military-police-force-the-continued-militarization-of-public-security-in-mexico/ [dostęp: 23.06.2019].

17. Moloeznik M.P. (2014), Balance of the National Security Strategy and the Performance of the Armed Forces in Mexico, 2006-2012, „Teka Komisji Politologii Stosunków Międzynarodowych PAN", vol. 9. 
18. Olson E. L. (2017), The Evolving Mérida Initiative and the Policy of Shared Responsibility in U.S.-Mexico Security Relations, https://www.wilsoncenter.org/sites/default/files/the_evolving_merida_initiative_and_the_policy_of_shared_responsiblity_in_u.s.-mexico_security_relations_0.pdf. [dostęp: 23.06.2019].

19. Peña Nieto's Challenge: Criminal Cartels and Rule of Law in Mexico (2013), "Latin America Report" N48/19 March, https://d2071 andvip0wj.cloudfront.net/Peña-nietos-challenge-criminal-cartels-and-rule-of-law-in-mexico.pdf [dostęp: 27.06.2019].

20. Presidente Felipe Calderón Hinojosa (2006), http://calderon.presidencia.gob.mx/oficina-de-la-presidencia/presidente/ [dostęp: 10.06.2019].

21. Programa Nacional de Seguridad Pública 2008-2012, (2008), http://www.ssp.df.gob.mx/ TransparenciaSSP/MAdmvoVarios/5Planes\%20PNSP\%202008_2012.pdf [dostęp: 24.06.2019].

22. Programa para la Seguridad Nacional (2009-2012), (2009), dof.gob.mx/nota_to_doc.php?codnota $=5106080$ [dostęp: 24.06.2019].

23. Sabia D., Kohler V. (2008), The 2006 Mexican Presidential Election: Democratic Developmentor Democratic Debacle?, "Journal of Third World Studies", 25 (1).

24. Sánchez Díaz de Rivera M.E. (2011), The challenges in the relationship between state and nation. The Mexican case, „Annales”, vol. XVIII, 1, sectio K, Lublin.

25. Sepczyńska D. (2010), W poszukiwaniu najlepszego modelu polityki. C. Schmitt, J. Rawls, Ch. Mouffe, [w:] Współczesne dylematy filozofii i kultury, red. D. Sepczyńska, J. Błahut-Prusik, P. Wasyluk, Olsztyn.

26. Skowronek T. (2014), Narkotykowy kult w Meksyku, http://geopolityka.org/analizy/tomasz-skowronek-narkotykowy-kult-w-meksyku [dostęp: 27.06.2019].

27. Small Arms Survey (2012), When Business Gets Bloody: State Policy and Drug Violence, http:// www.smallarmssurvey.org/fileadmin/docs/A-Yearbook/2012/eng/Small-Arms-Survey-2012Chapter-2-summary-EN.pdf. [dostęp: 16.06.2019].

28. Sotomayor A. C. (2013), Militarization in Mexico and its implications, https://core.ac.uk/download/pdf/36739258.pdf [dostęp: 19.06.2019].

29. Wiśniewski M. (2010), Licznik Śmierci, https://www.tygodnikpowszechny.pl/licznik-smierci-142876 [dostęp: 17.06.2019].

30. Ziółkowski J. (2013), Wrogość w stosunkach politycznych. Modelowa analiza funkcjonalna, Warszawa. 